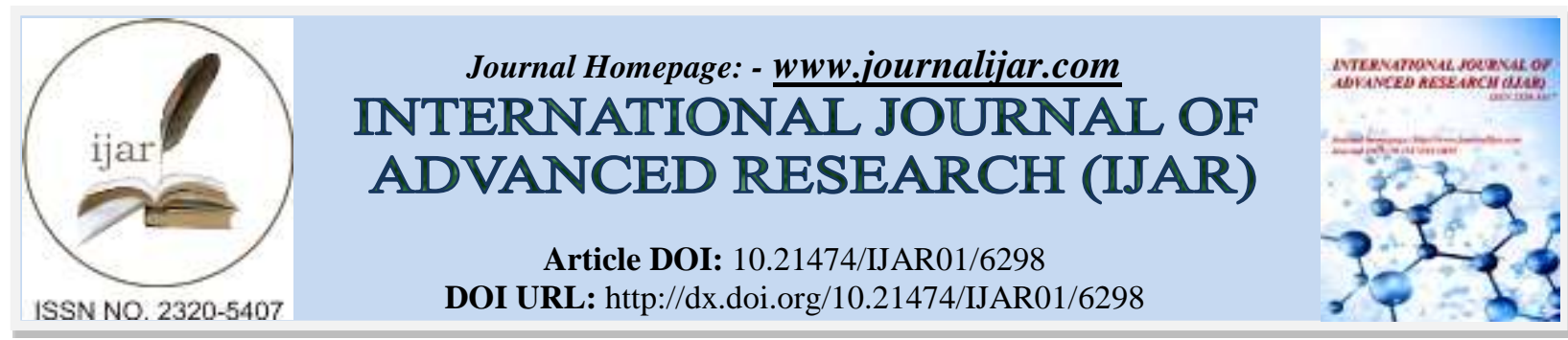

RESEARCH ARTICLE

\title{
LEARNING STYLE: ENGINEERING STUDENTS VS MANAGEMENT STUDENTS.
}

Dr. Jyoti Vyas Bajpai ${ }^{1}$ Mr. Anshul Pratap Singh Raghuwanshi ${ }^{2}$ Mr. Akshay Ramesh Taskar ${ }^{2}$.

1. Director, School of BFSI, Symbiosis University of Applied Sciences, Indore.

2. Student, MBA (BFSI), School of BFSI, Symbiosis University of Applied Sciences, Indore.

\section{Manuscript Info}

Manuscript History

Received: 13 November 2017

Final Accepted: 15 December 2017

Published: January 2018

Key words:-

VAK (Visual, Auditory and

Kinesthetic), Learning style,

Management, Engineering.

\begin{abstract}
Learning style is an individual's approach to perceive, learn and respond to a learning environment. One of the most important use of learning style is that it helps the teacher to make the process of teaching easy by incorporating them into their teaching process. Understanding individual's learning style open doors to the infinite possibility of gaining knowledge. The present study investigated learning styles among the graduate and postgraduate students of Symbiosis University of Applied Sciences, Indore. The respondents were divided into two groups, engineering students pursuing B.tech and management students pursuing B.B.A and M.B.A. The tool used for the present study is Barsch learning style inventory Questionnaire. The study revealed that the learning mode of engineering and management students differs with a preference towards visual mode, auditory mode and kinesthetic mode. Engineering and Management course students differ significantly in their preference for visual, auditory and kinesthetic learning mode. There are many theories of learning like classical conditioning, operant conditioning, cognitive learning and social learning but a common concept says that individuals differ in how they learn.
\end{abstract}

Copy Right, IJAR, 2018,. All rights reserved.

\section{Introduction:-}

"Every child has a different learning style and pace. Each child is unique, not only capable of learning but also capable of succeeding."- Robert John Meehan

Learning is one of the important psychological processes determining the human behavior. The complex way in which the human beings behave is all learned. If we want to explain and predict behavior, we need to understand how people learn. The psychologists say the human being, unlike animals, possess an extremely high proportion of unused mental capacity at birth. It is of course, unfavorable in its initial years because he will feel helpless. But in the later years, as he grows older, this unused mental capacity will help him in adapting to changed conditions and circumstances. This unused mental capacity will be used with the help of learning. In fact, practically all human behavior is directly or indirectly affected by learning. There are many theories of learning like classical conditioning, operant conditioning, cognitive learning and social learning. Learning style of the student changes from one student to another. They learn material in different ways, some learn by watching the things, some by listening to them while the others by doing practical work. Individuals thus differ in the way they learn. Learning style can be described as a set of factors, behaviors and attitudes that facilitate learning for an individual in a given situation. This style also influences how the student learns, how the teacher teaches and how the two interact. 
Several researchers proved that the type of cells that are present in some brains are not present in others and that is responsible for the different pattern of perception among individuals. Visual learners learn visually by means of charts, graphs, and pictures. Auditory learners learn by listening. Kinesthetic learners learn by doing. Students can prefer one, two, or three learning styles. Because of these different learning styles, it is vital for teachers to amalgamate their study program, these learning styles so that all students are able to succeed in their courses.

\section{Literature Review:-}

To start with our paper on the topic Learning styles: Engineering students Vs. Management students we referred, analyzed and studied some research paper related to this topic. (Abbas Pourhossein Gilakjani, 2012) concluded that the purpose of using learning styles is to find the best ways for both students to learn efficaciously and teachers to teach precisely [1]. (Rajshree S Vaishnav, 2013) in her paper concluded that there exists a significant effect of different styles and academic achievement of students [2]. (Veena N and Shailaja Shastri, 2013) concluded that there was a significant difference in learning styles and preferences among different category of students [3]. (Aminu Yabo Umar, 2015) in his thesis concluded that use of differentiation by visual, auditory and kinesthetic learning style has the potential of enhancing academic performance in ecology, scientific attitude and emotional intelligence among NCE students [4]. (Deeksha thakur, A K Vij and Charu shri, 2017) in their paper concluded that learning style inventories are of major assistance in identifying learning preferences of individuals and these also help in reaching potential strengths and areas of improvement in how learners deal with content as well as learning activities. These inventories help in reaching unique features of each individual and hence this concept deserves unique attention [5].

\section{Research Objective:-}

1. To find out the learning style of engineering students.

2. To find out the learning style of management students.

3. To compare the learning style of engineering students and management students.

\section{Research Methodology:-}

The research was conducted on a sample size of 88 students amongst which 44 are engineering students and other 44 are management students of Symbiosis University of Applied Sciences, Indore. The study was conducted in month of November of 2017. On the basis of learning styles students are divided into three group viz visual, auditory and kinesthetic learner.

Following is the analysis of the Barsch learning style inventory questionnaire:

Engineering Students:-

\begin{tabular}{|l|l|l|}
\hline Visual preference score & Auditory preference score & Kinesthetic preference score \\
\hline 11 & 18 & 15 \\
\hline
\end{tabular}




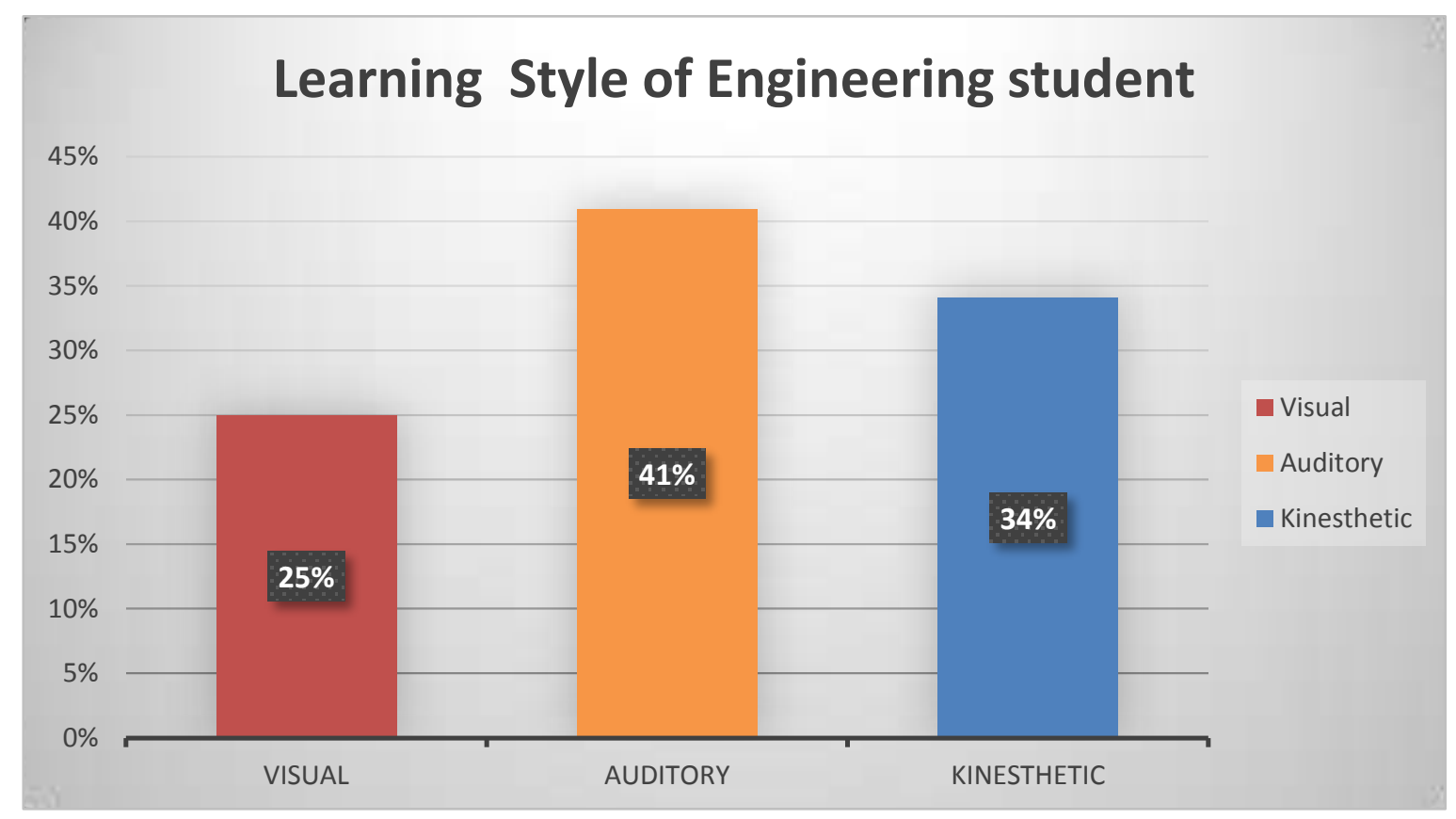

Management Students:-

Visual preference score

Auditory preference score

Kinesthetc preference score

22

12

10

\section{Learning style of Management student}

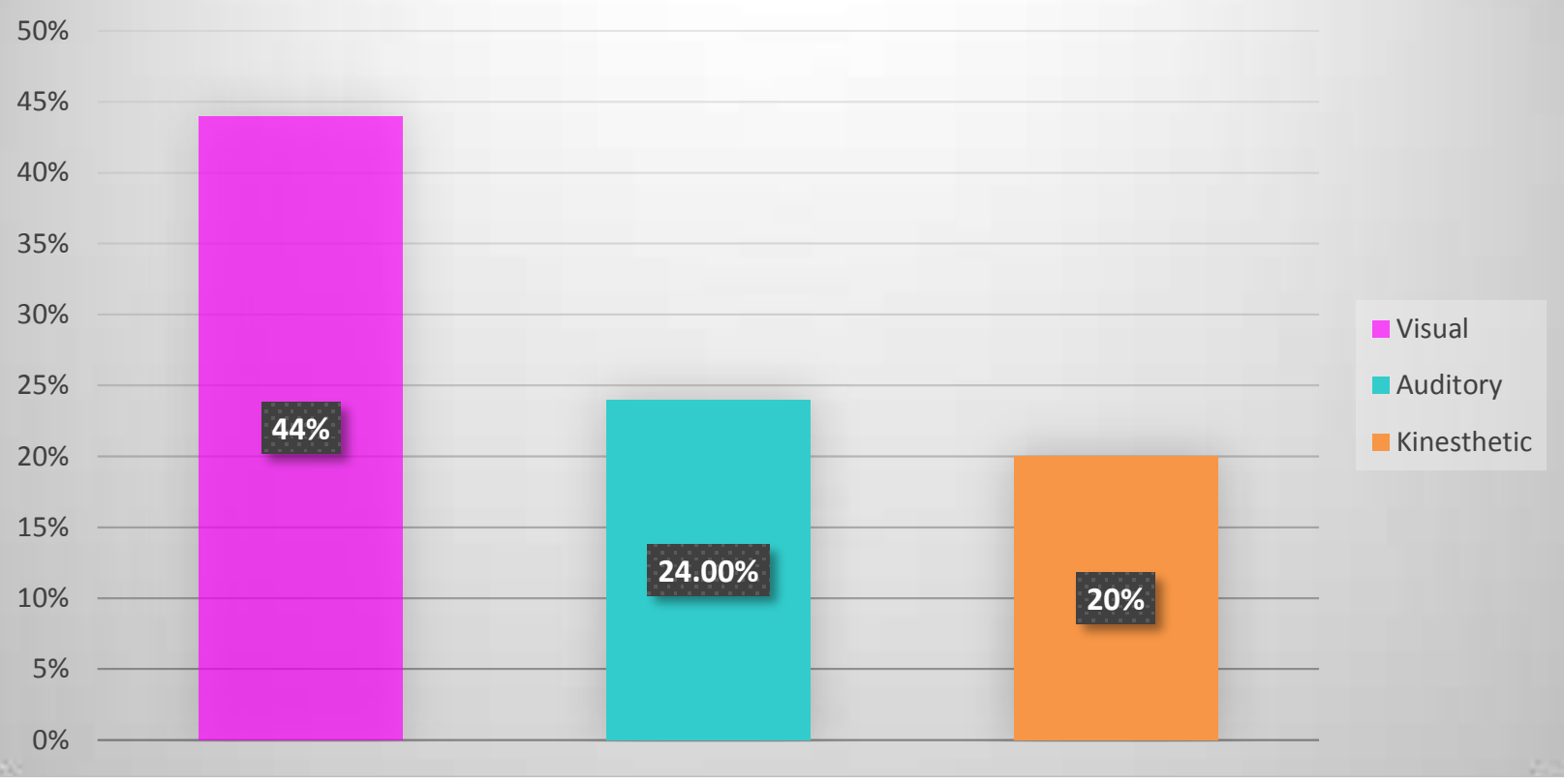




\section{Comparison between Engineering Students and Management Students:-}

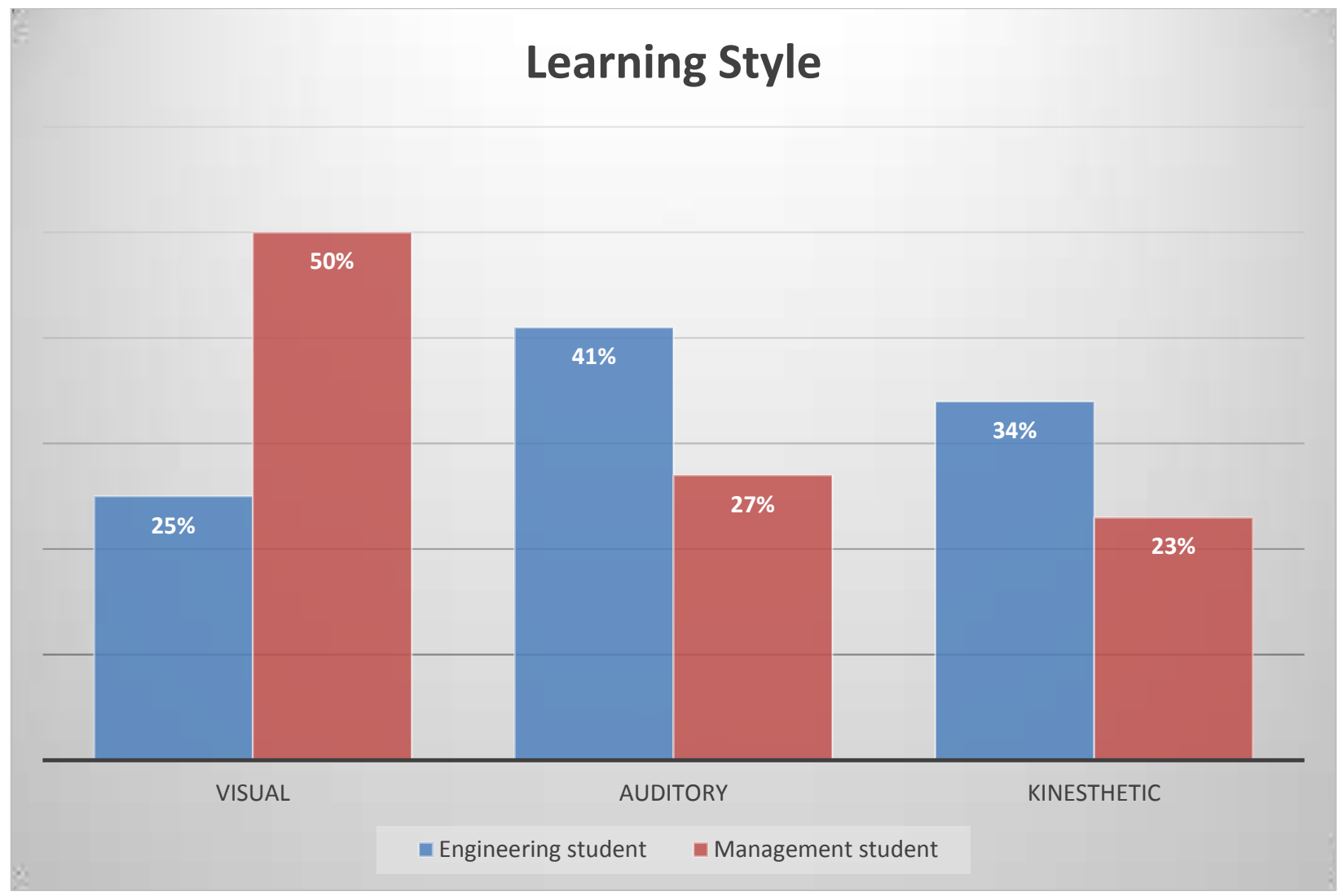

The result says that there is a significant difference in the learning style of engineering students and management students. $25 \%$ of engineering students prefer visual style of learning, $41 \%$ prefer auditory style of learning and remaining $34 \%$ prefer kinesthetic style of learning whereas in case of management students $50 \%$ are visual learner, $27 \%$ are auditory and remaining $23 \%$ are kinesthetic learner. Majority of management student (50\%) prefer visual style of learning while majority of engineering $(41 \%)$ student prefer auditory style of learning.

\section{Discussion and Conclusion:-}

A better knowledge and understanding of learning styles may become important as classroom sizes increase and as technological advances continue to mold the types of students entering higher education. While research in this area continues to grow, teachers should make concentrated efforts to teach in a multi-style fashion that both reaches the greatest extent of students in a given class and challenges all students to grow as learners. It is very important to understand and explore each individual's learning style. Analyzing one's own particular learning style can be very helpful and beneficial to the student by aiding them in becoming more focused on an attentive learner, which ultimately will increase educational success.

\section{Limitation/ Future Scope of Study:-}

The major limitation faced during the research was the availability of time, people and money. The present study required more responses. But due to lack of time there are only few responses. The sample size is limited to student of Symbiosis University of Applied sciences in Indore city. The teaching style also influences the learning style of students but is not considered in the present study. The participant in this research are resident of urban area only. Therefore this result can be generalized to similar population only.

The same kind of study might carry further for longer span of time with larger samples size. The further study can also cover more aspects related to learning style. The study can be done for other streams like Law, Medicine, Arts, Commerce, and Sciences etc. 


\section{References:-}

1. Gilakjani Abbas Pourhossein, 2012, "Visual, Auditory, Kinesthetic Learning Styles and Their Impacts on English Language Teaching", Journal of Studies in Education ISSN 2162-6952, Vol. 2, No.1.

2. Vaishnav Rajshree S, 2013, "Learning Style and Academic Achievement of Secondary School Students", Voice of Research, ISSN No. 2277-7733 Vol. 1 Issue 4.

3. Shastri Veena N, Shailaja, 2013, "Learning Preferences among Students", IOSR Journal Of Humanities And Social Science (IOSR-JHSS) Volume 15, Issue 6, PP 26-32 e-ISSN: 2279-0837, p-ISSN: 2279-0845.

4. Umar Aminu Yabo, 2015, "Effects Of Visual, Audio, Kinesthetic Learning On Emotional Intelligence, Attitude And Performance In Ecology Among Colleges Of Education Students" School of Postgraduate Studies, Ahmadu Bello University, Zaria, Nigeria.

5. Thakur Deeksha, Vij A K, Shri Charu, 2017, "Matching Teaching Pedagogy with Learning Styles of StudentsInsights through Literature Review" International Journal of Emerging Research in Management \&Technology ISSN: 2278-9359 (Volume-6, Issue-5)

6. Gupta Shashi K, Joshi Rosy, 2017, “Organizational Behaviour" $10^{\text {th }}$ Edition (ISBN 978-93-272-6795-4) chapter 8 published by Kalyani publishers.

7. J. M. Reid, 1987, " The learning style preferences of ESL students," TESOL Quarterly 21 (1), pp. 87-111.

8. Pallapu P., 2008, “An Exploratory Study of Undergraduate Students' Learning Styles”, Doctoral dissertation, UMI No 3333140.

9. Cassidy S, 2004, "Learning styles: an overview of theories, models and measures", Educational Psychology, 24(4), 419-444

10. Reynolds M., 1997, "Learning styles: a critique". Management Learning, 28, 115-133

11. Boström L. and Hallin K., 2013, "Learning Style Differences between Nursing and Teaching Students in Sweden- A Comparative Study", International Journal of Higher Education, 22-34. 